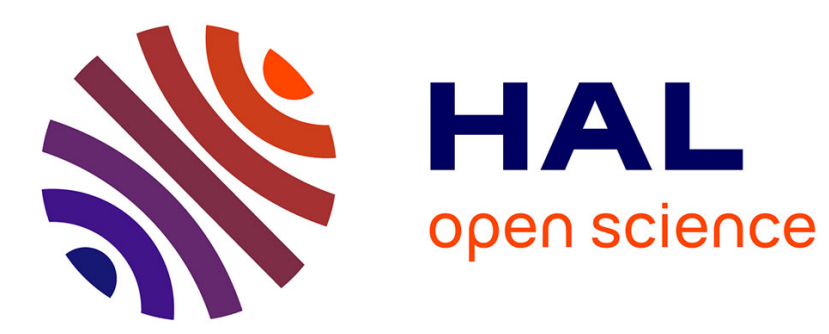

\title{
COOPERATIVE - RADIATION DYNAMICS IN 130Te2 AND 125Te2
}

J. Mezziane, E. Boursey, A. Topouzkhanian

\section{To cite this version:}

J. Mezziane, E. Boursey, A. Topouzkhanian. COOPERATIVE - RADIATION DYNAMICS IN 130Te2 AND 125Te2. Journal de Physique IV Proceedings, 1991, 01 (C7), pp.C7-533-C7-536. 10.1051/jp4:19917140 . jpa-00250814

\section{HAL Id: jpa-00250814 https://hal.science/jpa-00250814}

Submitted on 1 Jan 1991

HAL is a multi-disciplinary open access archive for the deposit and dissemination of scientific research documents, whether they are published or not. The documents may come from teaching and research institutions in France or abroad, or from public or private research centers.
L'archive ouverte pluridisciplinaire HAL, est destinée au dépôt et à la diffusion de documents scientifiques de niveau recherche, publiés ou non, émanant des établissements d'enseignement et de recherche français ou étrangers, des laboratoires publics ou privés. 
COOPERATIVE - RADIATION DYNAMICS IN ${ }^{130} \mathrm{Te}_{2}$ AND ${ }^{125} \mathrm{Te}_{2}$

J. MEZZIANE, E. BOURSEY and A. TOPOUZKHANIAN

Laboratoire de Spectrométrie Ionique et Moléculaire, C.N.R.S. U.A. 171, Université Claude Bernard, Lyon I, F-69622 Villeurbanne, France

\begin{abstract}
We present new results on $\mathrm{Te}_{2}$ superfluorescence induced by short YAG-pumped dye laser pulses analyzed at high resolution by comparison with $C$.W. laser induced fluorescence observed by Fourier transform spectroscopy. A complete identification of the transitions involved based on intensity measurements and supported by calculated Franck-Condon factors has been achieved. The cooperative emission in $\mathrm{Te}_{2}$ has been studied by time resolved spectroscopy as a function of density. As the density or temperature of the sample is increased, the emission evolves continuously from characteristic spontaneous emission to superfluorescence. The dependence of the superradiant pulse parameters ( relaxation time and half-width ) with respect to density will be presented and compared to predictions of current theories .
\end{abstract}

Laser induced fluorescence is a widely diffused technique however data analysis in gas phase are mostly based on the hypothesis of isolated species. One must remind that in such a situation a molecule is always surrounded by other partners either in excited state or ground state. Hence under some particular conditions it is not surprising to observe manifestation of cooperative processes between excited species. This is the case for superfluorescence (S.F.) which is a cooperative emission from a system excited by a coherent pulse into a "correlated" state which has a macroscopic electric dipole. Then the superradiant pulse is due to the emission of this dipole. Fundamentally in this case no macroscopic dipole is initially present in the molecular system; the phenomenon is started by normal fluorescence emission. Later on the system spontaneously creates correlations i.e. a macroscopic dipole which gives rise to a pulse whose maximum intensity is proportional to $\mathrm{N}^{2}$ and whose time duration is proportional to $\mathrm{N}^{-1}$.

We present here such a phenomenon observed with the dimer of the metal $\mathrm{Te}$ in the vapour phase (1). Superfluorescence of $\mathrm{Te}_{2}$ has been achieved by optical pumping with a dye pumped Nd-YaG laser from Quantel in the $22500 \mathrm{~cm}^{-1}-27000 \mathrm{~cm}^{-1}$ range and linewidth less than $0.2 \mathrm{~cm}^{-1}$. Laser beam was focused into a brewster all quartz tellurium filled cell and set into an oven. Temperature of the oven was monitored between $600^{\circ} \mathrm{C}$ and $800^{\circ} \mathrm{C}$. At this temperature the vapour pressure of $\mathrm{Te}_{2}$ is roughly 1 Torr. Emission light was focused onto the entrance slit of a $1,5 \mathrm{~m}$ Ebert Fastie monochromator equipped with a 1800 $1 / \mathrm{mm}$ grating and a photomultiplier. Spectra have been recorded in the second order of the instrument, and wavelength calibration achieved by superposing with the help of a pierced mirror the atomic lines emitted in a Fe-Ne hollow cathode lamp to the $\mathrm{Te}_{2}$ emission. Spectra were recorded through an ammeter and time evolution at fixed wavelength through a transient digitizer $125 \mathrm{MHz}$ LeCroy 9400 oscilloscope. Resolution of the set-up was about $0,03 \AA$ and 1 ns for time dependence.

The three figures below illustrate the phenomenon observed with ${ }^{130} \mathrm{Te}_{2}$ and ${ }^{125} \mathrm{Te}_{2}$. 

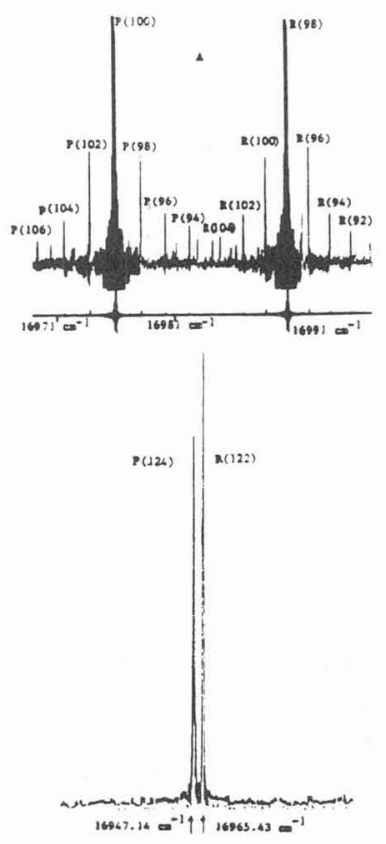

Fig. 1

Time Resolved Spectroscopy of ${ }^{130} \mathrm{Te}_{2}$

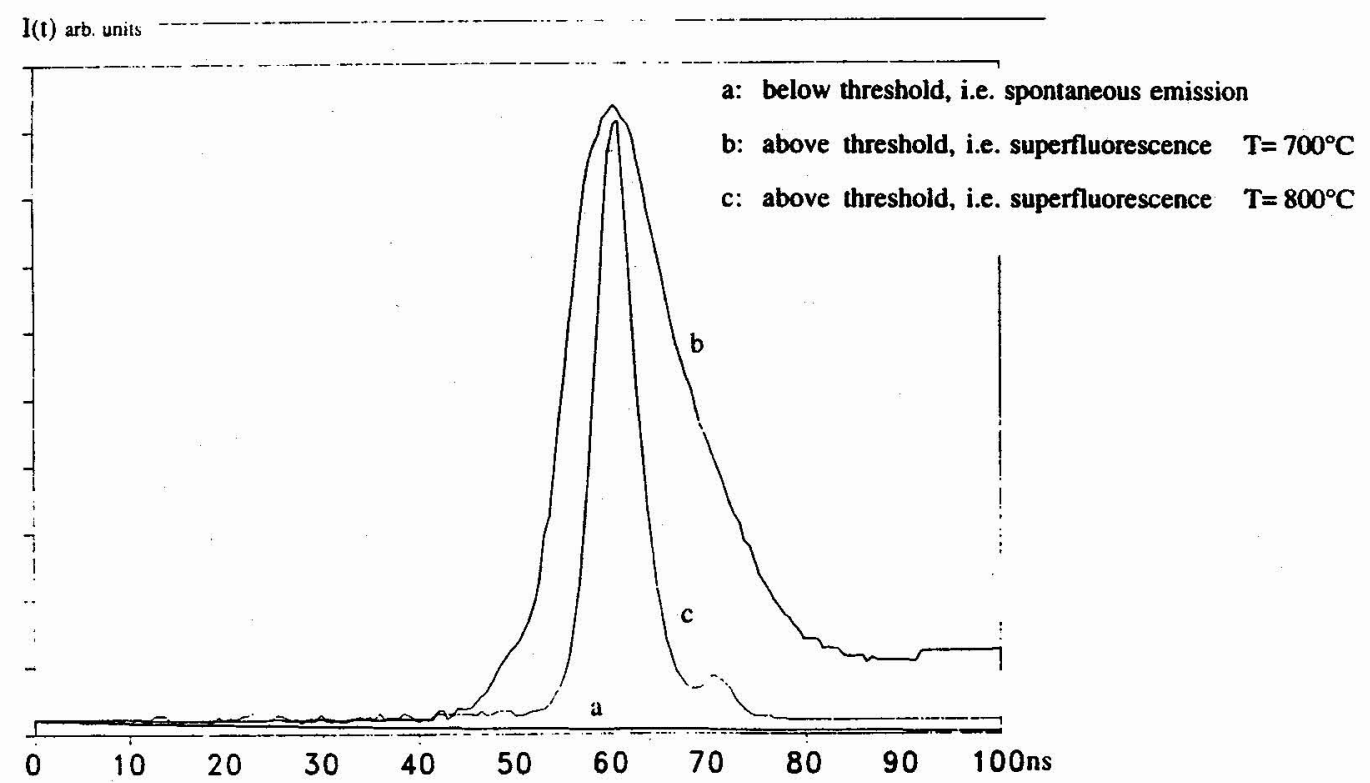

Fig. 2 
Time Resolved Spectroscopy of ${ }^{125} \mathrm{Te}_{2}$

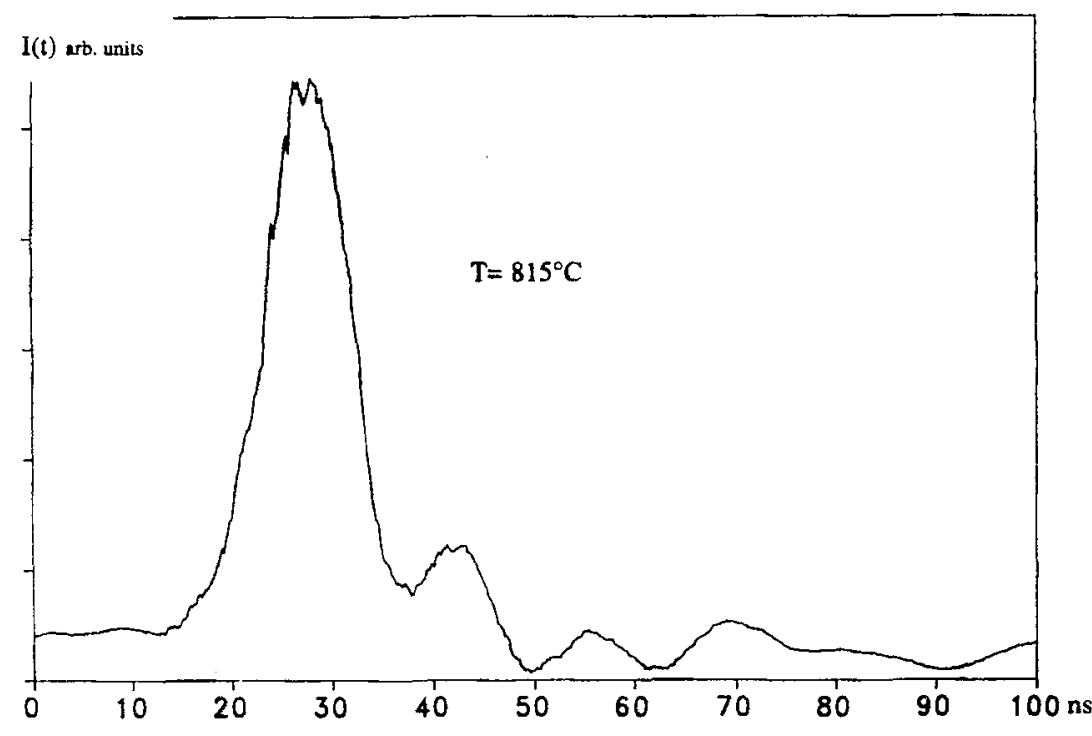

Fig. 3

Fig. 1a presents CW laser induced fluorescence and analyzed by Fourier transform spectroscopy. Fig. 1b presents analogous spectrum but with pulsed excitation as described previously.

Comparison between two spectra leads to the following remarks :

i) Rotational relaxation has disappeared in S.F., this is not surprising since population of relaxed levels do not reach inversion population threshold.

ii) Intensities between $P$ and $R$ lines are not identical as in $C W$ excitation. One can remark that ground level are respectively $J+1$ and $J-1$. Then it should appear a fast relaxation process $\left(10^{-12} \mathrm{~s}\right)$ from $J+1$ $\notin \mathrm{J}-1$ and $S . F$. is govemed by population inversion; hence intensity difference reflects $\mathrm{J}+1 \in \mathrm{J}-1$ transitions.

Fig. 2 displays time resolved S.F. at fixed wavelength above and below threshold and with the same time origin (2). It can be noticed :

i) As spontaneous emission starts at about $t=0$, building of S.F. takes about $60 \mathrm{~ns}$ which represents setting up of correlation between molecules.

ii) Full width at half maximum and decay time of S.F. decreases as $\mathrm{N}$ increases.

Fig. 4 displays fit of signal by analytical expression of $I(t)$ derived by Bonifacio et al.(3). This model is based on a general non perturbative quantum mechanics treatment of $\mathbf{N}$ two levels partners. The resulting dipole moment is calculated for partners arranged in a cubic lattice and inhomogeneous broadening is taken into account. Hence result of fit in Fig. 3 takes only consideration of experimentally measured parameters as delay time ( $60 \mathrm{~ns}$ ) and decay time $(4,5 \mathrm{~ns})$, intensities being normalized to experimental value. 


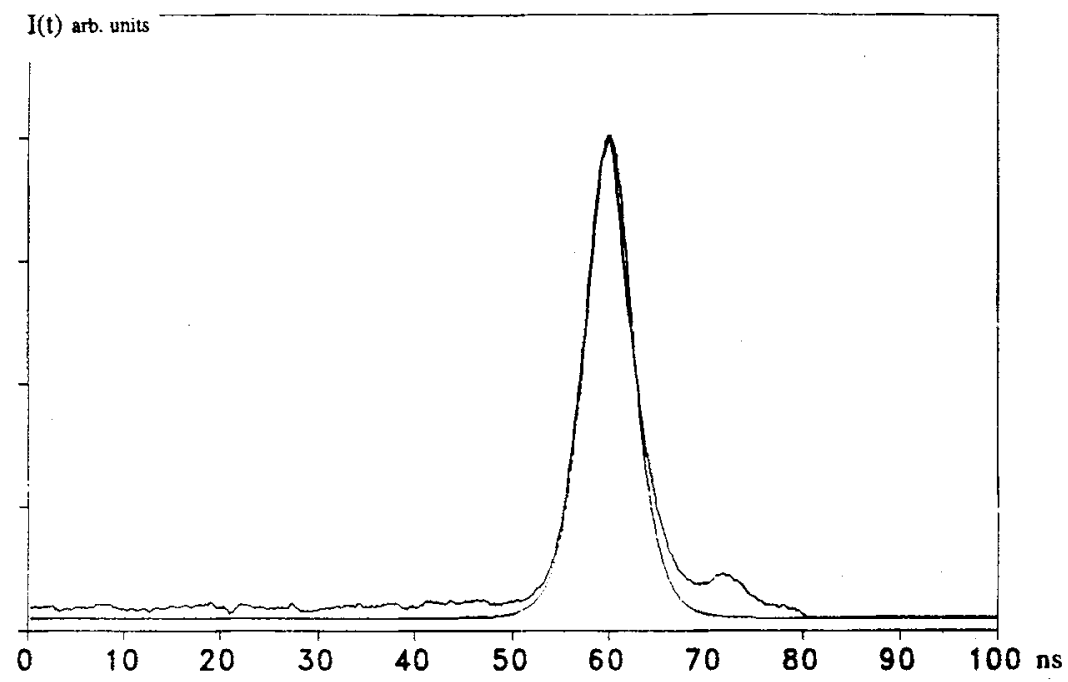

Fig. 4

/1/ BOURSEY E, DAMANY H, D'INCAN J, EFFANTIN C, TOPOUZKHANIAN A, Opt. Com. 68 (1988) 114.

12/ BOURSEY E, MEZIANE J, TOPOUZKHANIAN A, to be published.

13/ BONIFACIO R, LUGIATO L A, Phys. Rev. A 11 (1975) 1507. 